J. Lake Sci. (湖泊科学), 2011, 23(3): 395-400

http: //www.jlakes.org. E-mail: jlakes@niglas.ac.cn

(C) 2011 by Journal of Lake Sciences

\title{
新疆艾比湖精河入湖口退化湿地恢复过程中浮游植物群落的变化*
}

\author{
董正武 ${ }^{1}$, 赵晓英 ${ }^{1 * *}$, 陈丽华 $^{2}$, 任振华 ${ }^{1}$ \\ $(1$ : 新疆师范大学生命科学学院,乌鲁木齐 830054$)$ \\ (2: 艾比湖湿地国家级自然保护区管理局,博乐 833400$)$
}

摘 要: 精河人湖口湿地是新疆艾比湖湿地的重要组成部分. 本文通过空间序列代替时间序列的方法,对艾比湖精河人 湖口退化湿地不同恢复期的浮游植物群落特征进行分析, 结果表明, 恢复早期和中期硅藻种类最多, 绿藻在密度上占明 显优势, 恢复近期硅藻为主要优势类群. 恢复早期及自然区浮游植物群落结构较为稳定, 中期和近期群落结构不够稳定, 易受外界环境的影响. 艾比湖精河人湖口退化湿地各恢复时期浮游植物群落结构尚不完善, 仍需进一步改善. 在季节变 化上,浮游植物种类和密度以夏季最多,春季次之, 秋季最低; 春、秋季以硅藻为主要优势类群,夏季绿藻为主要优势类 群, 蓝藻在夏季密度高于其它各季节. 对各恢复期浮游植物和环境因子进行相关性分析表明, 温度、盐度和总磷是影响浮 游植物种类和数量的主要因素.

关键词: 不同恢复期;浮游植物;群落组成;季节变化;湿地;艾比湖;精河人湖口

\section{Phytoplankton community changes during wetland restoration in Jinghe Estuary, Lake Ebinur, Xinjiang}

DONG Zhengwu $^{1}$, ZHAO Xiaoying ${ }^{1}$, CHEN Lihua ${ }^{2} \&$ REN Zhenhua $^{1}$

(1: College of Life Science, Xinjiang Normal University, Urumqi 830054, P. R. China)

(2: Administrative Bureau of the National Nature Reserve in the Ebinur Lake Wetland, Bole 833400, P. R. China)

Abstract: The Jinghe Estuary wetland is one of the main proportions in wetlands of Lake Ebinur, Xinjiang. By using the method of spacial investigation, phytoplankton community was analysed in the wetland of Jinghe Estuary under different restoration stages. The results indicated that in the restoration process, species number of Bacillariophyta was the most diversified in the early and middle stage of the restoration, while Chlorophyta was abundant. Bacillariophyta was dominated in the late stage of the restoration. The structure of phytoplankton community was steady in natural site and in the early stage of restoration, but that was not steady in the middle and late stage of restoration. The species composition and abundance in summer were higher than in spring and autumn. In spring and autumn, Bacillariophyta was the first dominant group in the phytoplankton community. In summer, Chlorophyta became the main dominant group. Cyanophyta in summer had a higher abundance than in spring and autumn. Canonical Correspondence Analysis of phytoplankton and environmental data for all sites showed that temperature, total phosphorus and salinity influenced on the phytoplankton community composition and abundance.

Keywords: Different restoration stages; phytoplankton; community composition; seasonal variation; wetland; Lake Ebinur; Jinghe Estuary

艾比湖湿地位于新疆北部准噶尔盆地西南隅, 属于典型的干旱区湖泊湿地, 是准噶尔盆地西南缘最低 洼地和水盐汇集中心 ${ }^{[1]}$. 精河人湖口湿地是艾比湖湿地的重要组成部分, 由于各种因素的影响,精河人湖口 湿地生态环境退化严重, 主要表现在水资源的短缺,使精河人湖口湿地严重缺水,已影响到该地区社会经济 的可持续发展. 艾比湖湿地自然保护区从 2004 年开始每年围堰引水对精河人湖口退化湿地进行恢复. 在恢

* 新疆维吾尔自治区重大科技项目 (200833118) 和新疆师范大学珍稀濒危物种保护生物学重点实验室项目联合资助. 2010-04-21 收稿;2010-09-29 收修改稿. 董正武,男,1988 年生,硕士研究生; E-mail : dongzw2010@ sina. com.

** 通讯作者; E-mail: zzhaoxy@163.com. 
复措施实施前, 由于水资源的短缺, 该湿地部分地区处于干涸状态, 其地貌及土壤条件基本一致; 恢复措施 实施后,每年恢复的湿地引水量一定,水质条件基本一致.

浮游植物是湿地生态系统的初级生产者, 其组成与多样性的变化将直接影响到湿地生态系统的结构与 功能 ${ }^{[2]}$, 因此, 浮游植物对维持湿地生态系统平衡至关重要 ${ }^{[3]}$. 同时, 浮游植物具有一定的环境指示意义, 其 组成、结构及数量可以反映水质状况 ${ }^{[4]}$.

国内学者主要对寒带安邦河湿地 ${ }^{[5]}$ 、鄂尔多斯高原盐沼湿地 ${ }^{[6]}$ 、长江口九段沙湿地 ${ }^{[7]}$ 、长江口及邻近海

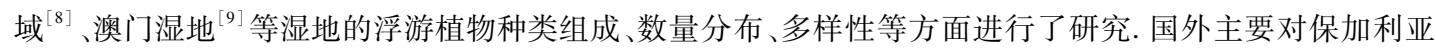
浅水湿地 ${ }^{[10]}$ 、澳大利亚 Myall 湿地 ${ }^{[11]}$ 等湿地的浮游植物群落结构及动态进行了研究. 艾比湖湿地自然保护 区浮游植物种类组成 ${ }^{[1]}$ 及水产养殖过程中水质状况调查 ${ }^{[12]}$ 已有初步报道, 但对精河人湖口退化湿地恢复中 浮游植物群落结构的研究还未见报道. 本文通过空间序列代替时间序列方法对艾比湖精河人湖口退化湿地 不同恢复期浮游植物的群落组成动态及水质指示意义进行探讨, 为艾比湖精河人湖口退化湿地恢复中浮游 植物群落演替以及湿地恢复状况的研究提供理论基础.

\section{1 材料和方法}

艾比湖精河入湖口湿地位于新疆博尔塔拉州东北部 $\left(44^{\circ} 30^{\prime}-44^{\circ} 96^{\prime} \mathrm{N}, 82^{\circ} 36^{\prime}-82^{\circ} 89^{\prime} \mathrm{E}\right)$. 气候为典型的 温带大陆性气候, 年平均气温 $6-8^{\circ} \mathrm{C}$, 日照时数约为 $2800 \mathrm{~h}$, 年平均降水量 $90.9 \mathrm{~mm}$, 年蒸发量高达 $3790 \mathrm{~mm}$ 以上, 年平均大风 ( 风速大于 $17 \mathrm{~m} / \mathrm{s}$ ) 天数高达 $165 \mathrm{~d}^{[1]}$. 本次调查共选择了不同年份恢复的 6 个样区, 各样区 水深 $0.5-1.3 \mathrm{~m}$, 平均水深约为 $1.0 \mathrm{~m}$.

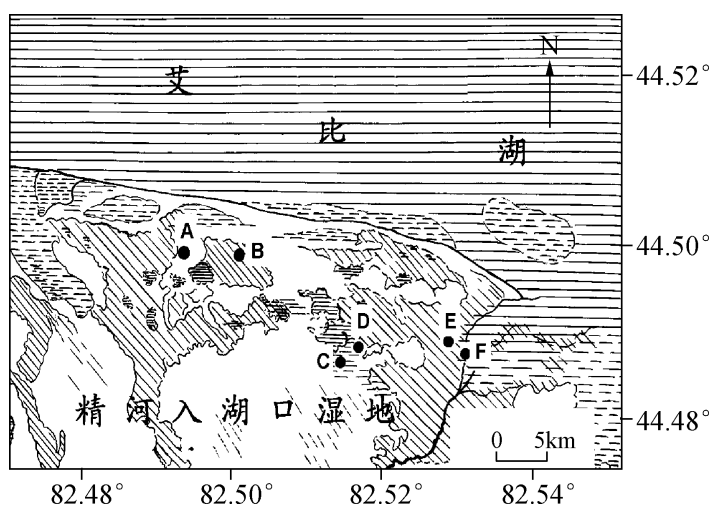

图 1 艾比湖精河人湖口退化湿地不同恢复时期 采样点示意图

( A : 自然区, B:2009 年引水区, C:2004 年引水区, $\mathrm{D}: 2005$ 年引水区, $\mathrm{E}: 2007$ 年引水区, $\mathrm{F}: 2008$ 年引水区)

Fig. 1 Sampling stations under different restoration stages in wetland in Jinghe Estuary, Lake Ebinur

\section{1 样区选择}

$2004-2009$ 年,保护区在精河人湖口退化湿 地每年围堰引水进行恢复, 该恢复区地形及土壤 条件基本一致 ${ }^{[13]}$. 在每年恢复的湿地选择取样点, 2004 年 $(C)$ 和 2005 年 (D) 围堰引水的代表恢复早 期,2007 年 (E) 的代表恢复中期, 2008 年 (F) 和 2009 年 (B) 的代表恢复近期. 另外, 在临近恢复地 的一块未退化的、保持原状的湿地代表自然区 ( A ) (图 1).

\section{2 浮游植物样品的采样与分析}

于 2009 年 5 月 (春季)、8 月 (夏季) 和 10 月 (秋季) 采集浮游植物样品, 每个样区选择 3 个采 样点, 定性样品采用 $25^{\#}$ 浮游生物网分别在表层和 水面下 $0.5 \mathrm{~m}$ 处作 “ $\infty$ ”字型拖曳 $5 \mathrm{~min}$, 收集样品 加适量 $5 \%$ 甲醛固定液保存, 待镜检. 定量样品用 有机玻璃采水器分别在表层和 $0.5 \mathrm{~m}$ 层各取水样 $1 \mathrm{~L}$, 混合后用鲁哥试剂现场固定, 室内用 $1 \mathrm{~L}$ 柱形 分液漏斗式的沉淀浓缩器静置 $48 \mathrm{~h}$, 浓缩至 $30 \mathrm{ml}$ 保存, 分析时取均匀样品 $0.1 \mathrm{ml}$ 在 HL-JS 0.1 型计数框中于 Motic DMBA400-B 显微镜下进行种类鉴定 ${ }^{[2]}$ 和 计数, 每样计数 3 次, 取其平均值 ${ }^{[14]}$. 优势度 $(y)$ 计算公式为: $y=\left(n_{i} / N\right) \times f_{i}$, 式中, $N$ 为采集样品中所有物 种的总个体数, $n_{i}$ 为第 $i$ 种的总个体数; $f_{i}$ 为该种在各样品中出现的频率. 当 $y \geqslant 0.02$ 时, 确定为优势种 ${ }^{[15]}$.

\section{3 水样理化性质的测定}

在采集水样的同时用温度计现场测定水温, 在实验室用 PHS-4A 型智能酸度计电位法测定 $\mathrm{pH}$, 用烘干 称重法测定盐分含量, 用钼酸铵分光光度法测定总磷 ( TP), 用钠氏试剂分光光度法测定氨氮 $\left(\mathrm{NH}_{3}-\mathrm{N}\right)$, 用 HH-6 型化学耗氧量测定仪测定化学耗氧量 $(\text { COD })^{[16]}$. 


\section{4 数据分析}

利用 SPSS 13.0 统计分析软件对所测数据进行处理,通过单因素方差分析 (One-Way ANOVA) 检验差异 的显著性,浮游植物数量和环境因子相关分析采用线性 Pearson 法并进行 $t$ 检验.

\section{2 结果与分析}

\section{1 水体理化性质}

$\mathrm{pH}$ 值在春季为中性一偏碱性, 夏、秋季为偏碱性, 其中 $\mathrm{B}$ 区 $\mathrm{pH}$ 值最高. 春季平均温度为 $18.12^{\circ} \mathrm{C}$, 夏季为 $24.18^{\circ} \mathrm{C}, \mathrm{A}$ 区最高; 秋季平均温度为 $13.11^{\circ} \mathrm{C}$, 其中 $\mathrm{B}$ 区最高. C 区盐分含量各季节变化较大, $\mathrm{B}$ 区的盐分含 量最高, 其它各恢复区盐分含量均较低. $\mathrm{TP}$ 含量在秋季最高, 夏季 $\mathrm{C}$ 区最高, $\mathrm{B}$ 区最低. $\mathrm{NH}_{3}-\mathrm{N}$ 含量春季最 高,秋季次之,夏季最低(表 1 ).

表 1 艾比湖精河入湖口退化湿地恢复中水体理化性质

Tab. 1 Water physico-chemical factors in rehabilitating wetland in Jinghe Estuary, Lake Ebinur

\begin{tabular}{|c|c|c|c|c|c|c|c|c|c|}
\hline \multirow{2}{*}{ 指标 } & \multicolumn{3}{|c|}{ 季节 } & \multicolumn{6}{|c|}{ 采样点 } \\
\hline & 春季 & 夏季 & 秋季 & $\mathrm{C}$ & D & $\mathrm{E}$ & $\mathrm{F}$ & B & A \\
\hline $\mathrm{pH}$ & 7.43 & 8.38 & 7.91 & 7.62 & 7.94 & 7.93 & 7.91 & 8.44 & 7.95 \\
\hline 温度 $\left({ }^{\circ} \mathrm{C}\right)$ & 18.12 & 24.18 & 13.11 & 18.52 & 18.52 & 15.37 & 17.44 & 20.54 & 21.22 \\
\hline 盐度 $(\mathrm{mg} / \mathrm{L})$ & 3.89 & 4.58 & 3.82 & 6.60 & 1.38 & 0.93 & 1.17 & 15.44 & 1.26 \\
\hline $\mathrm{TP}(\mathrm{mg} / \mathrm{L})$ & 0.06 & 0.06 & 0.19 & 0.12 & 0.12 & 0.10 & 0.09 & 0.12 & 0.10 \\
\hline $\mathrm{NH}_{3}-\mathrm{N}(\mathrm{mg} / \mathrm{L})$ & 0.45 & 0.28 & 0.40 & 0.35 & 0.37 & 0.38 & 0.29 & 0.29 & 0.53 \\
\hline
\end{tabular}

\section{2 浮游植物种类组成}

$\mathrm{E}$ 区与 A 区均以硅藻占优势, 绿藻次之; C、D 区与 B、F 区春秋季均以硅藻在种类数上占优势,而夏季绿 藻的种类数多于硅藻. 蓝藻在 $B 、 F$ 区最多, 在 $A$ 区的春秋季未出现, 隐藻在 $C 、 D$ 区未出现. 从各区总种数来 看, A 区种类数最多 (76 种), C、D 区种类数 (68 种) 多于 E 区 (63 种) 和 B、F 区 (59 种). 从季节变化来看, 浮 游植物种数在夏季最高, 春季次之, 秋季最低. 其中春秋季硅藻种类最多, 绿藻次之; 夏季以绿藻最多, 硅藻 次之;蓝藻在各季节居第三, 甲藻、金藻和裸藻种类较少 (图 2a).

\section{3 浮游植物数量}

$\mathrm{B} 、 \mathrm{~F}$ 区浮游植物的密度最高, 达 $91.67 \times 10^{4}-190.01 \times 10^{4} \mathrm{cells} / \mathrm{L}$; E 区次之, 为 $16.67 \times 10^{4}-159.22 \times$ $10^{4}$ cells $/ \mathrm{L}$; C、D 区最低, 为 $18.33 \times 10^{4}-58.32 \times 10^{4}$ cells $/ \mathrm{L}$; A 区介于 C、D 区和 $\mathrm{E}$ 区之间, 为 $18.33 \times 10^{4}-$ $111.12 \times 10^{4} \mathrm{cells} / \mathrm{L} . \mathrm{C} 、 \mathrm{D}$ 区春季硅藻密度最多, 夏秋季绿藻密度最多, 占总数量的 $66.0 \% \mathrm{E}$ 区及 A 区在春 秋季以硅藻密度最多, 夏季绿藻密度最多. E 区蓝藻的密度高于其它各区, B、F 区硅藻和绿藻的密度高于其 他各区, 占总数量的 $86.34 \%$. 从季节变化分析表明, 浮游植物密度在夏季最高, 其次为春季, 秋季最低. 硅藻
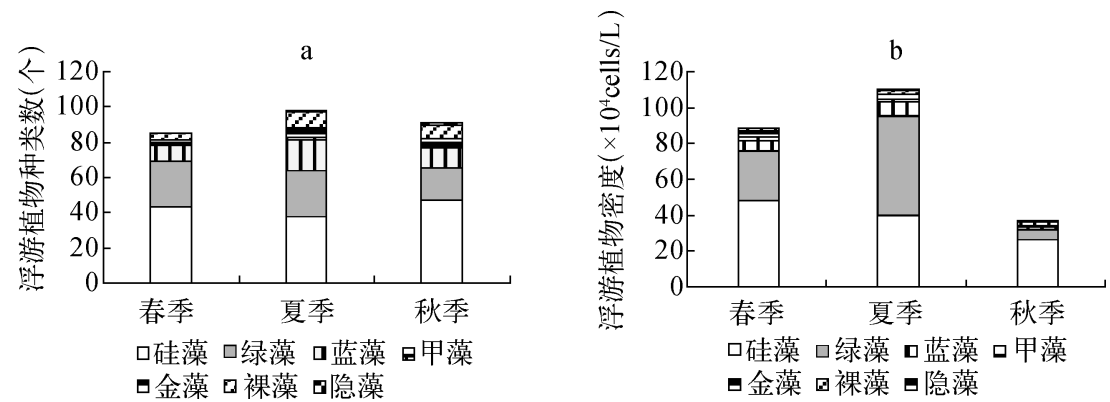

图 2 精河入湖口退化湿地恢复中不同季节浮游植物种类组成 (a) 和密度 (b)

Fig. 2 Seasonal dynamics of phytoplankton species(a) and density(b) in rehabilitating wetland in Jinghe Estuary 
的密度在春季最高, 其次为秋季, 夏季最低, 绿藻密度在夏季占绝对优势, 蓝藻的密度在夏季高于其它各季 节 (图 2b).

\section{4 浮游植物群落优势种}

C、D 区主要优势种有小球藻、不定微囊藻、细纹长篦藻等, 尖针杆藻、龟背基枝藻、不定微囊藻为 $\mathrm{E}$ 区的 主要优势种, B、F 区主要有尖针杆藻、短线脆杆藻、钝脆杆藻等硅藻, 短肋羽纹藻、小球藻等为 A 区的主要优 势种 (表 2). 春季优势种主要有硅藻门的短小舟形藻、短肋羽纹藻, 蓝藻门的边缘微囊藻等. 夏季优势种主要 有绿藻门的龟背基枝藻、小球藻, 硅藻门的短线脆杆藻等; 球衣藻、绿色颤藻仅为夏季的优势种. 秋季优势 种主要有硅藻门的细纹长篦藻、钝脆杆藻、短线脆杆藻, 绿藻门的小球藻等; 绿色裸藻仅为秋季的优势种 (表2).

表 2 精河入湖口退化湿地恢复中浮游植物群落主要优势种

Tab. 2 Phytoplankton dominant species in rehabilitating wetland in Jinghe Estuary

\begin{tabular}{|c|c|c|c|c|c|c|c|}
\hline \multirow{2}{*}{ 季节 } & \multirow{2}{*}{ 优势种 } & \multicolumn{6}{|c|}{ 采样点 } \\
\hline & & $\mathrm{C}$ & $\mathrm{D}$ & $\mathrm{E}$ & $\mathrm{F}$ & B & A \\
\hline \multirow[t]{5}{*}{ 春季 } & 短小舟形藻 Navicula exigua & V & & & & & \\
\hline & 克洛脆杆藻 Fragilaria crotonensis & & V & & & & \\
\hline & 尖针杆藻 Synedra acus & & & V & V & & \\
\hline & 边缘微囊藻 Microcystis marginata & & & V & & & \\
\hline & 短肋羽纹藻 Pinnularia brevicostata & & & & & & $\sqrt{ }$ \\
\hline \multirow[t]{6}{*}{ 夏季 } & 龟背基枝藻 Basicladia chelonum & V & V & V & V & V & \\
\hline & 小球藻 Chlorella vulgaris & V & V & & & & $\sqrt{ }$ \\
\hline & 不定微囊藻 Microcystis minutissima & & V & V & V & & \\
\hline & 短线脆杆藻 Fragilaria brevistriata & & & & & V & \\
\hline & 球衣藻 Chlamydomonas globosa & & & & & & $\sqrt{ }$ \\
\hline & 绿色颤藻 Oscillatoria chlorina & & & & & & $\sqrt{ }$ \\
\hline \multirow[t]{6}{*}{ 秋季 } & 细纹长篦藻 Neidium affine & V & V & & & & \\
\hline & 窗格平板藻 Tabellaria fenestrata & & & V & & & \\
\hline & 小球藻 Chlorella vulgaris & & & & V & & \\
\hline & 针脆杆藻 Fragilaria capucina & & & & & V & \\
\hline & 短线脆杆藻 Fragilaria brevistriata & & & & & V & V \\
\hline & 绿色裸藻 Euglena viridis & & & & V & & \\
\hline
\end{tabular}

\section{5 浮游植物与环境因子的关系}

春季, 短肋羽纹藻密度与盐度呈极显著负相关, 与 $\mathrm{TP}$ 呈极显著正相关. 夏季, 浮游植物种数与温度、 $\mathrm{TP}$ 分别呈极显著负相关和显著负相关, 与盐度呈显著正相关. 浮游植物密度也与 TP 呈显著负相关. 小球藻密 度与温度呈显著负相关. 秋季, 浮游植物密度与 $\mathrm{pH}$ 、温度和盐度均呈极显著正相关, 细纹长篦藻密度与 $\mathrm{TP}$ 呈极显著正相关, 钝脆杆藻密度与盐度和 $\mathrm{NH}_{3}-\mathrm{N}$ 浓度分别呈显著负相关和极显著负相关 (表 3 ).

\section{3 讨论}

\section{1 不同恢复期浮游植物的群落组成}

在湿地生态系统恢复中,一般来说浮游植物种数多、数量低, 并且优势种的优势度较低, 说明浮游植物 群落结构较为稳定, 水质好 ${ }^{[17]}$. 在精河人湖口退化湿地恢复中, 浮游植物种数为恢复早期高于中期和近期, 数量和主要优势种的优势度恢复早期低于中期和近期, 表明恢复时期越早, 浮游植物群落结构越稳定, 治理 效果显著. 另外, 在恢复早期的湿地, 水体中有丝叶眼子菜、芦苇等水生植物, 这有利于水体的净化. 自然区 水体属于静水水体, 受人为的干扰较小, 浮游植物种数最多, 优势种较多, 且优势种的优势度较低, 群落结构 较为稳定. 恢复早期群落组成与自然区具有一定的相似性, 表明随着恢复时间的延长, 浮游植物群落趋于 稳定. 
董正武等: 新疆艾比湖精河入湖口退化湿地恢复过程中浮游植物群落的变化

表 3 精河入湖口退化湿地恢复中浮游植物与环境因子的相关性

Tab. 3 The correlation between phytoplankton and environmental factors in rehabilitating wetland in Jinghe Estuary

\begin{tabular}{cccccrrr}
\hline 季节 & 浮游植物 & $\mathrm{pH}$ & 温度 & 盐度 & $\mathrm{TP}$ & $\mathrm{NH}_{3}-\mathrm{N}$ & $\mathrm{COD}$ \\
\hline 春季 & 浮游植物种数 & -0.078 & 0.325 & 0.227 & 0.003 & -0.227 & 0.405 \\
& 浮游植物密度 & 0.269 & -0.096 & -0.141 & -0.037 & -0.328 & 0.409 \\
& 小球藻密度 & 0.309 & -0.163 & -0.447 & 0.520 & -0.268 & -0.502 \\
& 短肋羽纹藻密度 & 0.957 & -0.775 & $-0.975^{* *}$ & $0.988^{* *}$ & 0.443 & -0.837 \\
夏季 & 浮游植物种数 & -0.376 & $-0.633^{* *}$ & $0.566^{*}$ & $-0.520^{*}$ & -0.155 & -0.204 \\
& 浮游植物密度 & 0.148 & -0.355 & 0.403 & $-0.543^{*}$ & -0.199 & -0.074 \\
& 龟背基枝藻密度 & -0.891 & 0.308 & -0.181 & -0.334 & 0.882 & $-0.706^{*}$ \\
& 小球藻密度 & -0.288 & $-0.619^{*}$ & -0.473 & -0.123 & -0.144 & 0.262 \\
秋季 & 浮游植物种数 & -0.084 & 0.138 & 0.279 & 0.017 & 0.033 & 0.211 \\
& 浮游植物密度 & $0.893^{* *}$ & $0.743 * *$ & $0.930^{* *}$ & 0.240 & -0.126 & 0.423 \\
& 细纹长篦藻密度 & 0.114 & 0.583 & -0.375 & $0.961 * *$ & -0.971 & -0.619 \\
& 钝脆杆藻密度 & $0.583^{*}$ & 0.060 & $-0.779 *$ & 0.705 & $-0.965 * *$ & -0.923 \\
\hline
\end{tabular}

* 表示在 0.05 水平,显著相关, **表示在 0.01 水平,极显著相关.

浮游植物种类组成是浮游植物对水体环境适应的结果 ${ }^{[5]}$. 在湿地恢复的不同时期, 由于环境因素的变 化, 导致浮游植物组成和数量发生不同变化 ${ }^{[17]}$. 在精河人湖口退化湿地恢复中, 恢复早期以硅澡为主, 多数 种类为贫 - 中营养化指示种 ${ }^{[18]}$. 恢复中期和近期, 硅藻种类数和绿藻相近, 但绿藻在数量上占优势, 种类多为 中-富营养化种类. 这表明随着恢复时间的延长, 水体环境有所改善, 更有利于一些能够在较好水体中生活 的浮游植物种类, 如硅藻等出现.

从优势种的指示性来看, 艾比湖精河人湖口退化湿地恢复早期和中期采样区主要优势种有小球藻、微 囊藻等中-富营养化指示种, 表明恢复早期和中期有不同程度的中一富营养化 ${ }^{[18]}$, 这可能与恢复早期和中期 样区进行水产养殖等有关. 由于小规模的水产养殖,养殖区内的排泄物、食物残渣很容易造成水体营养盐浓 度升高, 并且有机质含量较高 ${ }^{[12]}$, 从而使绿藻大量繁殖, 成为优势类群. 恢复近期主要优势种为脆杆藻、针杆 藻等中营养化指示种, 这一方面可能与近期恢复区没有进行水产养殖, 水体盐度较高等有关; 另一方面, 由 于近期恢复措施实施时间短, 新形成的水体环境 (营养盐等) 不足以维持现存种类生长繁殖,一些能够适应 该环境的硅藻等中营养型指示种获得生长和竞争优势并最终成为优势种.

在艾比湖精河人湖口湿地, 本次调查所得浮游植物的种类组成与 2002 年调查所获资料 ${ }^{[1]}$ 基本一致,但 在本次调查中出现以前尚未记录的种 (属). 造成种类组成差异的原因比较多, 其中恢复措施的实施可能是 主要原因之一.

\section{2 浮游植物群落的季节变化}

在温带地区, 年降水量少以及温度是引起浮游植物季节变化的重要非生物因素之一 ${ }^{[19]}$. 春、秋季水温较 低, 浮游植物群落以硅藻为主, 夏季水温高, 蓝藻和绿藻成为水体的优势类群 ${ }^{[20]}$.一般来说, 蓝藻、绿藻的生 长需要较高的温度, 其最适温度为 $25-35^{\circ} \mathrm{C}^{[21]}, 15^{\circ} \mathrm{C}$ 以下生长受到限制 ${ }^{[22]}$. 在艾比湖精河人湖口湿地, 春季 各采样点的水温较低, 浮游植物种类、数量及优势种以硅藻为主. 水体营养盐浓度较低, 为浮游植物生长提 供的营养较少, 造成春季浮游植物群落结构较简单. 夏季各样区的平均水温达到 $24^{\circ} \mathrm{C}$, 非常接近绿藻和蓝藻 生长繁殖的最适温度, 绿藻和蓝藻的种类和数量较多, 优势种 (属) 主要有龟背基枝藻以及微囊藻等. 夏季营 养盐浓度较高, 水温比较适合多种浮游植物的生长, 浮游植物具有较为复杂的群落结构. 秋季由于温度的降 低, 浮游植物种类和数量较少, 群落结构相对简单, 蓝藻和绿藻的优势度和数量降低, 硅藻的种类和数量增 加. 从浮游植物数量的季节变化看, 夏季浮游植物生长旺盛, 各调查区的数量均较高, 秋季浮游植物的数量 有大幅度的下降, 春季由于温度的上升, 浮游植物的数量出现上升, 因此秋季浮游植物数量低于春季.

致谢: 马晓东老师在藻类取样方案的设计中给予指导, 取样中得到艾比湖自然保护区的苏海林、热合曼以及 赵法、李晓梅、南江同学的大力帮助,特致谢忱! 


\section{4 参考文献}

[1] 陈蜀江, 候 平, 李文华等. 新疆艾比湖湿地自然保护区综合科学考察. 乌鲁木齐: 新疆科学技术出版社,2006.

[ 2 ] 胡鸿钧,魏印心. 中国淡水藻类一一系统、分类及生态. 北京: 科学出版社, 2006 .

[4] 沈韦是芬,章宗涉,龚循矩. 微型生物监测新技术. 北京: 中国建筑工业出版社, 1990.

[ 5] 覃雪波, 黄璞神, 刘曼红等. 安邦河湿地浮游植物数量与环境因子相关性研究. 海洋湖沼通报, 2008, (3) : 43-50.

[6] 刘文盈, 高润宏, 张秋良等. 鄂尔多斯高原盐沼湿地浮游植物的多样性与评价. 干旱区资源与环境, 2009, 23(5): 143-148.

[ 7 ] 吴 琼, 吴 波, 赵爱萍等. 长江口九段沙附近水体浮游植物的种类组成与数量分布. 上海师范大学学报 (自然科 学版), 2007, 36(1) : 54-59.

[ 8 ] 何 青,孙 军. 长江口及其邻近水域网采浮游植物群落. 生态学报,2009, 29(7): 3928-3938.

[ 9 ] 李秋华,何伟添,陈 椽. 澳门湿地浮游植物群落特征. 植物生态学报,2009, 33(4)：689-697.

[10] Stoyneva MP. Steady-state phytoplankton assemblages in shallow Bulgarian wetlands. Hydrobiologia, 2003, 502 : 169-176.

[11] Ryan NJ, Mitrovic SM, Bowling LC. Temporal and spatial variability in the phytoplankton community of Myall Lakes, Australia, and influences of salinity. Hydrobiologia, 2008, 608: 69-86.

[12] 韩生玮, 阿达可白克, 翟久军等. 2008 年艾比湖河蟹规模化绿色养殖技术小结. 新疆渔业科技,2008, (2): 12-18.

[13] 金海龙,白 祥,满中龙等. 新疆艾比湖湿地自然保护区土壤空间异质性研究. 干旱区资源与环境, 2010, 24 (2): 151-157.

[14] 章宗涉,黄祥飞. 淡水浮游生物研究方法. 北京: 科学出版社, 1991.

[15] 罗民波,陆健健,王云龙等. 东海浮游植物数量分布与优势种.生态学报,2007, 27(12): 5076-5085.

[16] 章家恩. 生态学常用实验研究方法与技术. 北京: 化学工业出版社,2007: 4.

[17] 刘冬燕, 赵建夫, 张亚雷等. 富营养水体生物修复中浮游植物的群落特征. 水生生物学报, 2005, 29(2) : 177-183.

[18] 福迪 B. 藻类学. 上海: 上海科学技术出版社, 1980 .

[19] Richardson TL, Gibson CE, Heaney SI. Temperature, growth and seasonal succession of phytoplankton in Lake Baikal, Seberia. Freshwater Biology, 2000, 44: 431-440.

[20 ] Sera T, Colomen J, Baserba C et al. Quantified distribution of diatom during the stratified period of Boadella Reservoir. Hydrobiologia, 2002, 589 : 235-244.

[21] Nalewajko C, Murphy TP. Effects of temperature and availability of nitrogen and phosphorus on the abundance of anabaena and microcystis in Lake Biwa, Japan: an experimental approach. Limnology, 2001, (2) : 45-48.

[22] Robarts RD, Zohary T. Temperature effects on photosynthetic capacity, respiration, and growth rates of bloom-forming cyanobacteria. Marine Freshwater Research, 1987, 21 : 391-399. 